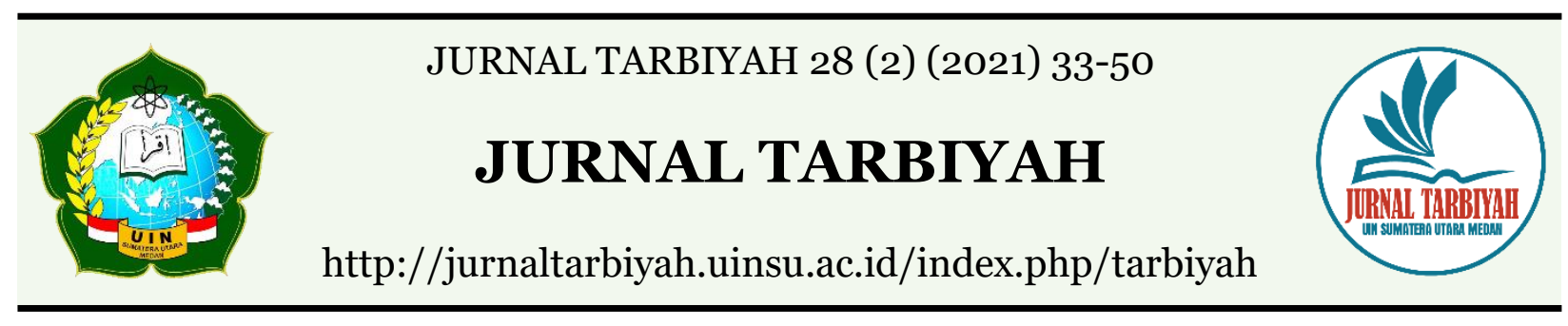

\title{
THE IMPLEMENTATION OF LEARNING MANAGEMENT IN IMPROVING THE QUALITY OF ISLAMIC EDUCATION FOR STUDENTS AT MTSN 2 LANGKAT
}

\author{
Sudirman \\ Kantor Kementerian Agama Kabupaten Langkat \\ Email: sudirmansemsi@gmail.com
}

DOI : 10.30829/tar.v28i2.1110

Accepted: October 1st, 2021. Approved: December 28th, 2021. Published: December 30th, 2021

\begin{abstract}
Students need for qualified Islamic education is strongly influenced by the implementation of a systematic, programmed, and measurable learning management. This study aims to describe the implementation of learning management in improving the quality of Islamic education for students at MTsN 2 Langkat. This empirical study follows a qualitative approach with a descriptive-analytical study method. The data were collected through interviews, observation, and documentation analysis. The implementation of learning management can improve the quality of Islamic education for students at MTsN 2 Langkat. Improving the quality of education can be seen from the following aspects: (1) learning planning that involves all parties during the deliberation/meeting at the Madrasah, (2) the implementation of learning carried out in the Madrasah (inside and outside the classroom) as well as the tahfiz al-Qur'an program and the congregational Dhuha prayer; (3) learning supervision carried out systematically with academic and managerial supervision from the Ministry of Religion in the district and the Head of the Madrasah; (4) learning evaluation carried out in written, in worship practice and orally every semester.
\end{abstract}

Keyword: Implementation, Quality of Islamic Education, Learning Management. 


\section{INTRODUCTION}

Islamic education (religion-based) is the responsibility of various parties, including parents, teachers, and the government (Taubah, 2015; Usman, 2017; Siregar, 2016). The fulfillment of the growth and development needs of students is pursued through the provision of learning facilities in formal and non-formal educational institutions (Djaelani, 2013). According to Sada (2017), the fundamental reason for facilitating education for children is because education (especially Islamic education) is a primary need for every individual. Furthermore, the constitution in Indonesia guarantees children the right to education (Fitri, et.al., 2015; Sujatmoko, 2010; Fitriani, 2016; Sudrajat, 2011).

The social interactions that children receive in formal educational institutions help children gain learning experiences related to the urgency of Islamic education (Nurmalitasari, 2015; Assingkily \& Mikyal, 2019). In this context, education is classified according to the age phase and level of development, starting from the level of early childhood education (PAUD), Raudlatul Athfal/Kindergarten to higher education (Sholikhah, et.al., 2019; Pamela, et.al., 2015; Putriani, 2015; Vitasari, 2017). Trenggonowati \& Kulsum (2018) added that apart from the childhood phase, it is important to pay attention to the golden age of each child. The adolescent phase is also important because it is the time when every individual is looking for their identity.

Given the importance of the adolescent phase, Notosrijoedono (2016) emphasize that parents are obliged to support and provide good Islamic education facilities to prepare the students' life in the future. Furthermore, Assingkily, et.al. (2019) add that the right direction for children has an impact on the adolescent phase and becomes the basis to survive various life challenges in the following phases.

An effort to realize a good quality of Islamic education in formal educational institutions is by implementing learning management in accordance with the developmental needs of adolescents (Munawaroh, 2017; Ita, 2018; Aryani \& Fitriani, 2020). The main priority of learning management is focused on moral and religious aspects (Khaironi, 2017; Hasanah, 2018; Inawati, 2017). In line with this view, Noor (2020) explains that teenagers will be more focused if they have an understanding of religion, at least they can develop a sense of tolerance and respect for others.

Based on the initial research conducted at MTsN 2 Langkat, it was found that this Madrasah implements learning materials through a persuasive approach, coupled with various excellent programs and Islamic activities in the Madrasah. Examples of these 
activities are such as the annual Islamic cultural festival, the celebration of Islamic holidays, the tahfiz al-Qur'an program, and the congregational Dhuha prayer.

Researches on the implementation of learning management have been widely conducted before, for example, researches discussing the aspects of learning management and its development in integrated Islamic educational institution (Saputro, 2016; Syafaruddin, et.al., 2020), 2013 curriculum-based learning management (Nurdyansyah \& Fahyuni, 2016), online learning (Agustin, et.al., 2020; Abadi, 2015), teachers' creativity (Supriadi, 2017), innovation through the hypnoteaching model (Mardhiah, et.al., 2020), teacher professionalism (Kristiawan \& Rahmat, 2018), learning in the 4.0 revolutionary era (Widyanto, et.al., 2020), and the management of history learning (Lilian, et.al., 2014).

Education is widely interpreted as an effort to "guarantee" the sustainability of human life (Rahmat, 2017; Hardana, 2015) because every human is caliph fil ardh who is in charge of managing the earth according to the Sunnatullah (Shahid, 2020; Thobroni, 2014; Widiantar, 2016). For this reason, strengthening education is focused on the learning aspect because various theories, components, and concepts of education are integrated and interact with each other in learning activities (Rahman, 2018; Pane \& Dasopang, 2017; Dolong, 2016).

According to Rosyad (2019), learning is an urgent matter in the educational process. Good and effective learning is carried out by the needs of the global community (Oviyanti, 2013; Dacholfany, 2015). This informs the importance of good management in the process of planning, implementing, monitoring, and evaluating learning (Khairuddin, 2020).

Referring to the four management functions above, learning needs to be managed in a measurable, programmed, and systematic way to improve the quality of Islamic education for students (Maujud, 2018; Almasri, 2016)

Learning planning is an initial concept or a basic framework for learning regularly which is planned on a scale of 6 months (a semester) or every 12 months (annually) in an educational institution (Nadlir, 2013; Nurlaila, 2018). In line with this, Prabowo (2010) explains that learning planning is inseparable from the orientation of educational goals.

Based on the previous literature above, further research is needed on the implementation of learning management that is oriented towards the realization of the high quality of Islamic education, especially for students in the adolescent phase. This study is entitled "The Implementation of Learning Management in Improving the Quality of Islamic Education for Students at MTsN 2 Langkat”. 


\section{RESEARCH METHOD}

This empirical study follows a qualitative approach with an analytical descriptive method to explore new things related to the object of the study (Yin, 2009). The focus of this study is to describe the implementation of learning management in improving the quality of Islamic education for students at MTsN 2. This research was conducted from February to May 2021, with the main informants including teachers and students of MTsN 2 Langkat, and the Head of MTsN 2 Langkat as the supporting informant.

The data collection was carried out through observation, interviews, and documentation. Furthermore, the data were analyzed through the following techniques, (1) data reduction as the process of sorting data, (2) narratively presenting the data, and (3) concluding. Furthermore, the validity o the research data is tested and carried out through the triangulation technique (Creswell, 2009). In this context, two aspects of triangulation were compared, namely method and data source. Therefore, the data were presented, and valid conclusions were drawn following the research context.

\section{RESULTS AND DISCUSSION}

\section{The Learning Planning at MTsN 2 Langkat}

This plan must be systematized, programmed, and measurable so that it is easy to be implemented and discussed.

In line with the statement above, the Head of MTsN 2 Langkat mentioned that:

“...in the process of determining lesson plan for a 6 month (a semester) and 1 year (annual) scale, we usually prioritize the principle of mutual benefit. This is the reason why we always involve teachers and educational personnel so that the meanings in Madrasah can produce a decision made together. We hope that in this way everyone feels responsible for carrying his/her duties, especially to improve the quality of learning and academic services for students. (an interview conducted with Roslita Hidayati, S.Ag.)

Baharuddin (a teacher of Akidah Akhlak) confirmed the statement above by saying that:

“...As a teacher as well as a homeroom teacher, I admit that the Madrasah should involve us in making a decision, especially the decision which relates to learning planning. He mentioned that the learning plan should fit the vision of the Madrasah. In a meeting, he often says "the decision belongs to us together, who knows I might be wrong as the head of the Madrasah, it is okay to remind each 
other, as long as we still pay attention to ethics and the common good" (an interview conducted with a teacher at MTsN 2 Langkat)

The following image shows the discussion on learning planning at MTsN 2 Langkat:

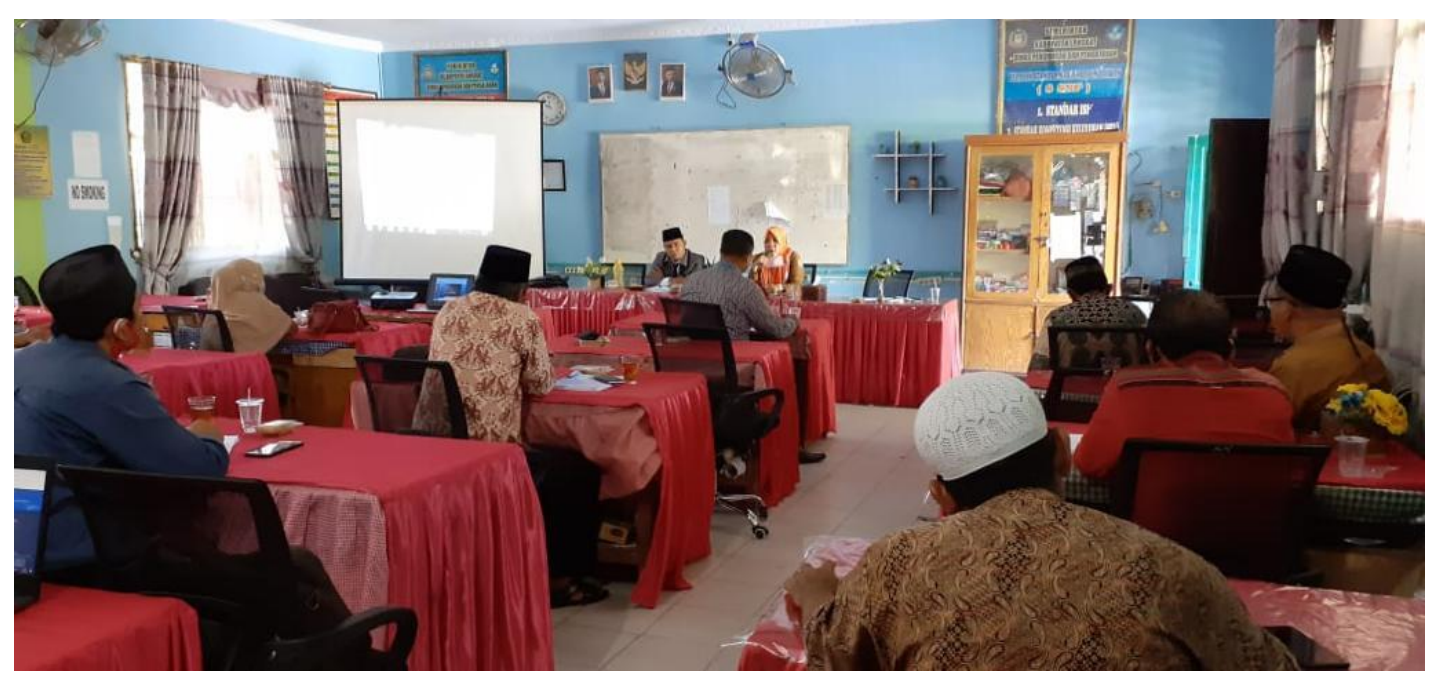

Figure 1. the Discussion of Learning Planning at MTsN 2 Langkat

Supporting the two excerpts of the interview above, Nurlaeli \& Saryono (2018) explain that the leader of an educational institution needs to involve his members in making a decision because this method (discussion/deliberation) is seen to be persuasive and familial. Bararah(2017) adds that this is the first step of preparing a programmed, systematic, and measurable learning plan. The next step taken by the Madrasah leader is to implement the learning programs that have been arranged creatively and innovatively for the development (and progress) of Madrasah.

Similarly, with the opinion above, the Head of MTsN 2 Langkat adds that:

"...as for the implementation of learning planning in our Madrasah, we carry this through deliberation. Meanwhile, the preparation of programs for each subject is given to the teachers to be flexible, creative, and innovative as much as possible, of course, this is following the principles of curriculum preparation. We hope the textual curriculum in Madrasah refers to the existing principles while the implementation will be more flexible. Likewise, as an Islamic educational institution (under the name of Madrasah), we strengthen the material for the love 
of Allah SWT and Rasulullah SAW through worship activities (an interview conducted with Mrs. Roslita Hidayati, S.Ag.)

Therefore, it will be directly proportional to the planning and the implementation of learning at MTsN 2 Langkat.

\section{The Implementation of Learning at MTsN 2 Langkat}

The implementation of learning at MTsN 2 Langkat is carried out contextually in the classroom (with the assistance of media) and outside the classroom. In this context, teachers play a very important role in assisting students' development, especially since the students are teenagers in the phase of finding their identity (Rahayu \& Firmansyah, 2018; Handayani \& Jumadi, 2021). Furthermore, the implementation of learning requires moral and material support from the Madrasah leaders to meet students' learning needs (Aziz, 2014; Rahim, 2015; Assingkily \& Mesiono, 2019; Supriadi, 2020).

Similar thing was also mentioned by a teacher at MTsN 2 Langkat:

“...the students of junior high school (SMP or MTs) are very active, they are not stubborn, but this is a phase where they are looking for an identity. Thus, we teach them something more practical than theoretical to let the students experience what they learn firsthand. This is what is called contextual learning. The theory given in the classroom is applied outside the classroom or in the classroom with the assistance of the media" (an interview conducted with Ernida, S.Pd.I., a teacher of Al-Qur'an and Hadith at MTsN 2 Langkat)

The interview excerpt above confirms the implementation of learning at MTsN 2 Langkat which is carried out contextually in the classroom (assisted by the media) and outside the classroom. Furthermore, Herman Sitorus, S.Pd. (the Deputy Head of Madrasah for Curriculum board at MTsN 2 Langkat) mentioned that, “...supporting the learning process in Madrasah, we agreed to add the tahfiz program and the dhuha prayer in the congregation as an effort to strengthen the character of students in the Madrasah." Such activities which were implemented by the Head of MTsN 2 Langkat aim to strengthen the Islamic character of students in the Madrasah. 
Following is the photo of Tahfiz Program at MTsN 2 Langkat:

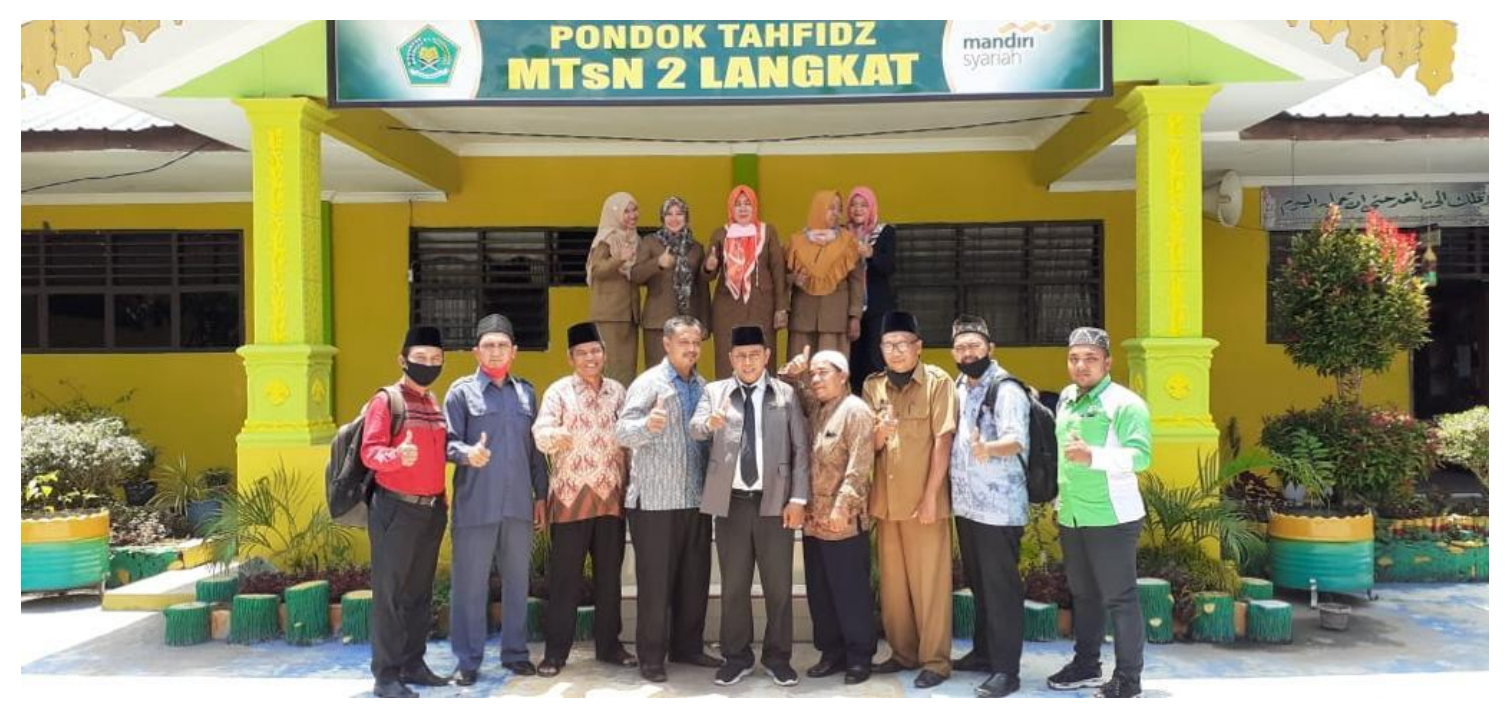

Figure 2. Tahfiz program at MTsN 2 Langkat

Furthermore, when an interview was conducted with a student at MTsN 2 Langkat, the student confirmed that the Tahfiz program and the Dhuha prayer are carried out at the Madrasah. This can be seen as follows:

“...That's right, every morning we perform congregational Dhuha prayer in the field. Except on Friday, we practice congregational Friday prayer in the field in the morning, and we take a turn in carrying out congregational prayer class by class in the Mushalla. Every morning we also review the memorization of Qur'an with a Tahfiz teacher. (an interview conducted with Irwandi, a student of Grade VII at MTsN Langkat)

Supporting the interview excerpt above, Lubis, et.al.(2020) mentioned that excellent programs and additional activities are the hallmarks of excellent Madrasah in shaping the personality (character) of active and intelligent students. According to Dewi (2018), sufficient activities given to students can help them in accelerating their development, not feeling bored with the situation, and always interacting with their peers. Thus, the moral and religious development of students at MTsN 2 Langkat can be supported well, and this can improve the quality of Islamic education for students.

\section{Learning Supervision at MTsN 2 Langkat}

The learning supervision at MTsN 2 Langkat was divided into managerial (administrative) and academic aspects. Through supervision, learning will be more 
controlled in writing, orally, and in practice as an effort to optimize the learning process (Meisusdawati, 2011; Ismail, 2016; Tonta, et.al., 2019).

Based on the information retrieved from Roslita Hidayati, S.Ag., it was noted that: "...the implementation of learning supervision in Madrasah was carried out by the supervisors from the Ministry of Religion (external aspect). Meanwhile, I am in charge of supervising the internal aspect of the Madrasah. The aspects which were monitored are, of course, managerial (administrative aspect) and academic" (an interview conducted with the Head of MTsN 2 Langkat).

The following image shows the supervision activity at MTsN 2 Langkat:

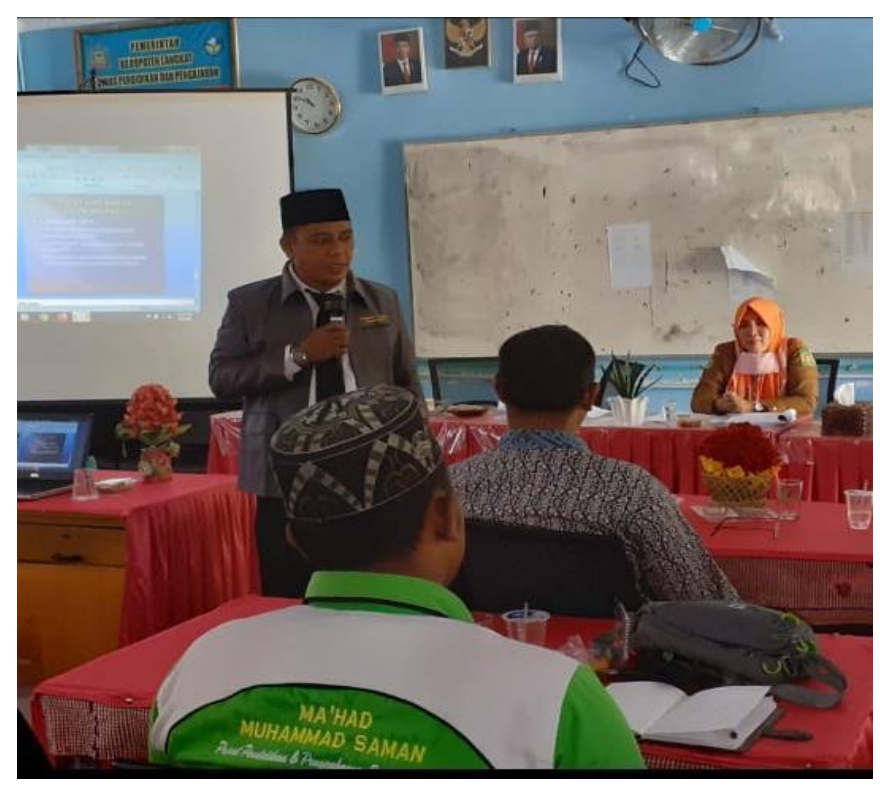

Figure 3. External Monitoring Activity at MTsN 2 Langkat

Thus, learning supervision at MTsN 2 Langkat was implemented internally (by the Head of Madrasah) and externally (by the Supervisors from the Ministry of Religion). The supervision was divided into 2 (two) aspects, namely administrative or managerial aspects, and academic aspect. Through this supervision, learning can be well controlled to improve the quality of education for students at the Madrasah.

\section{Learning Evaluation at MAN Batubara}

Within a management process, learning still has gaps for improvement (Nuriyah, 2016), at least quality improvement through creation, innovation, and learning development (Gunawan, 2011). This indicates the importance of evaluating the learning 
process and learning outcomes (Hidayat \& Asyafah, 2019; Alaswati, et.al., 2017; Anwar, 2021; Fachri, 2018). For this reason, Suardipa \& Primayana (2020) emphasize the importance of designing an effective learning evaluation to improve the quality of learning.

According to Rohmah (2017), learning evaluation is beneficial to improve the quality of the learning process. For this reason, educational institutions must facilitate the needs of academic and administrative evaluations so that the learning process and learning outcomes can be improved following the goals of the institution.

Regarding the learning evaluation, Roslita Hidayati, S.Ag., mentioned that:

“...the learning evaluation at our Madrasah is carried out through oral test, written test, and practice test. The oral test aims to measure students' ability to memorize and read the Qur'an, written test aims to measure students' cognitive abilities, and practice test aims to measure students' skills in carrying out daily worship activities" (results of an interview conducted with the Head of MTsN 2 Langkat).

The interview excerpt above informs the evaluation carried out by the Madrasah through written and oral tests as well as through worship practices. Likewise, it was explained that in the current globalization era, the evaluation of learning carried out in written and orally should not be monotonous from year to year without any changes. For this reason, learning evaluation and innovation are needed to prioritize students' development. Therefore, it is understood that the learning evaluation conducted at MTsN 2 Langkat aims not only to let the students take formal exams but also to improve moral and religious aspects.

\section{CONCLUSION}

Based on the results of the study, it is concluded that the implementation of learning management can improve the quality of Islamic education for students at MTsN 2 Langkat. This is viewed from the aspects of (1) learning planning that involves all parties in Madrasah regarding the deliberation activities; (2) the implementation of learning carried out in Madrasah (inside and outside the classroom) as well as the tahfiz al-Qur'an program and the congregational Dhuha prayer; (3) learning supervision carried out systematically which involves academic and managerial supervision from the Ministry of 
Religion in the district and the head of Madrasah; (4) learning evaluation carried out in written, through worship practices, and orally in every semester.

\section{REFERENCES}

Abadi, Ghafiki Faroek. (2015). "Inovasi Pembelajaran Pendidikan Agama Islam Berbasis E-Learning" Tasyri’: Jurnal Tarbiyah-Syariah Islamiyah, 22(2). http://ejournal.kopertais4.or.id/pantura/index.php/tasyri/article/view/1547.

Agustin, Farida, et.al. (2020). "Manajemen Pembelajaran Daring Menggunakan Education Smart Courses" Technomedia Journal, 5(1).

Ahmad, Sabaruddin. (2021). "Implementasi Supervisi Manajerial Pengawas dalam Meningkatkan Kinerja Guru PAI di MIN 4 Aceh Tenggara Era Covid-19” Mudabbir: Journal Research and Education Studies, 1(1). http://jurnal.permapendissumut.org/index.php/mudabbir/article/view/3.

Alaswati, Sri, et.al. (2017). "Evaluasi Pelaksanaan Pembelajaran Kurikulum 2013 PJOK” Journal of Physical Education and Sports, 5(2). https://journal.unnes.ac.id/sju/index.php/jpes/article/view/13447.

Almasri, M Nazar. (2016). "Manajemen Sumber Daya Manusia: Implementasi dalam Pendidikan Islam” Kutubkhanah: Jurnal Penelitian Sosial Keagamaan, 19(2). http://ejournal.uin-suska.ac.id/index.php/Kutubkhanah/article/view/2547.

Andiyanto, Tri. (2018). "Urgensi Supervisi Pendidikan dalam Meningkatkan Pengawasan

Satuan Pendidikan” Jurnal Pendidikan Payan Mas, 2(1). http://ejournal.disdikbudlu.org/index.php/ejournal/article/view/28.

Andriana, Karmila. (2015). "Urgensi Perencanaan Pembelajaran Bahasa Arab dalam Pendidikan di Sekolah” Prosiding Konferensi Nasional Bahasa Arab (Konasbara), 1. http://prosiding.arab-um.com/index.php/konasbara/article/view/22.

Ansori, M. Subhan, et.al. (2019). "Meningkatkan Pemahaman dan Keterampilan Ibadah Haji Bagi Peserta Didik, Guru, dan Wali Murid Melalui Pembelajaran Praktik Manasik Haji untuk Anak Usia Dini” JPPNu: Jurnal Pengabdian dan Pemberdayaan Nusantara, 1(1).

http://journal.unublitar.ac.id/jppnu/index.php/jppnu/article/view/3.

Anwar, Khoirul. (2021). "Urgensi Evaluasi dalam Proses Pembelajaran” Rausyan Fikr: $\begin{array}{llll}\text { Jurnal Pemikiran } \& \quad \text { Pencerahan, } & \text { 17(1). }\end{array}$

http://jurnal.umt.ac.id/index.php/RausyanFikr/article/view/4183.

Aryani, Rini \& Fitriani. (2020). "Inovasi Pembelajaran Pendidikan Kreatif” Prosiding 
Seminar Nasional PPS Universitas PGRI Palembang. https://jurnal.univpgripalembang.ac.id/index.php/Prosidingpps/article/view/3936.

Asmara, Yeni \& Dina Sri Nindianti. (2019). "Urgensi Manajemen Kelas untuk Mencapai Tujuan Pembelajaran" Sindang: Jurnal Pendidikan Sejarah dan Kajian Sejarah, 1(1). https://ojs.stkippgri-lubuklinggau.ac.id/index.php/JS/article/view/192.

Assingkily, Muhammad Shaleh \& Mikyal Hardiyati. (2019). "Analisis Perkembangan Sosial-Emosional Tercapai dan Tidak Tercapai Siswa Usia Dasar” Al-Aulad: Journal $\begin{array}{llll}\text { of Islamic Primary } & \text { Education, } & \text { 2(2): } & \text { 19-31. }\end{array}$ http://journal.uinsgd.ac.id/index.php/al-aulad/article/view/5210.

Assingkily, Muhammad Shaleh \& Mesiono. (2019). "Karakteristik Kepemimpinan Transformasional di Madrasah Ibtidaiyah (MI) serta Relevansinya dengan Visi Pendidikan Abad 21" MANAGERIA: Jurnal Manajemen Pendidikan Islam, 4(1). http://ejournal.uin-suka.ac.id/tarbiyah/index.php/manageria/article/view/2475. Assingkily, et.al. (2019). "Kearifan Menyikapi Anak Usia Dasar di Era Generasi Alpha (Ditinjau dari Perspektif Fenomenologi)" Attadib: Journal of Elementary Education, $3(2)$. https://jurnalfaiuikabogor.org/index.php/attadib/article/view/572.

Aziz, Fathul Aminudin. (2014). "Kepemimpinan Transformasional Kepala Madrasah dalam Implementasi Kurikulum 2013" Insania: Jurnal Pemikiran Alternatif Kependidikan, 19(1).

http://ejournal.iainpurwokerto.ac.id/index.php/insania/article/view/461.

Bararah, Isnawardatul. (2017). "Efektivitas Perencanaan Pembelajaran dalam Pembelajaran Pendidikan Agama Islam di Sekolah” Jurnal MUDARRISUNA: Media Kajian Pendidikan Agama Islam, 7(1). https://www.jurnal.arraniry.ac.id/index.php/mudarrisuna/article/view/1913.

Chotimah, Chusnul \& Muhammad Fathurrohman. (2018). Paradigma Baru Sistem Pembelajaran. Yogyakarta: Ar-Ruzz Media.

Creswell, John W. (2009). Research Design Qualitative, Quantitative, and Mixed Methods Approach. California: SAGE Publications, Inc.

Dacholfany, M. Ihsan. (2015). "Reformasi Pendidikan Islam dalam Menghadapi Era Globalisasi” Akademika: Jurnal Pemikiran Islam, 20(1). https://ejournal.metrouniv.ac.id/index.php/akademika/article/view/441.

Darussalam. (2020). "Urgensi Pengawasan Sekolah dalam Meningkatkan Kinerja Guru Pendidikan Agama Islam di SMPN Serbajadi Aceh Timur” Al-Qiraah, 14(2). 
http://jurnal.kopertais5aceh.or.id/index.php/al-qiraah/article/view/124.

Dewi, Bilqisti. (2018). "Peran Kepala Madrasah dalam Meningkatkan Program Unggulan

Madrasah” Jurnal ISEMA: Islamic Education Management, 3(1). https://journal.uinsgd.ac.id/index.php/isema/article/view/3284.

Djaelani, Moh. Solikodin. (2013). "Peran Pendidikan Agama Islam dalam Keluarga dan Masyarakat” Jurnal Ilmiah Widya, 1(2). $\underline{\text { https://e- }}$ journal.jurwidyakop3.com/index.php/jurnal-ilmiah/article/view/140.

Dolong, Jufri. (2016). "Teknik Analisis dalam Komponen Pembelajaran” Jurnal Inspiratif Pendidikan, 5(2). $\quad$ http://103.55.216.56/index.php/InspiratifPendidikan/article/view/3484.

Fachri, Moh. (2018). "Urgensi Evaluasi Pembelajaran dalam Pendidikan” Edureligia, 2(1). https://doi.org/10.33650/edureligia.v2i1.758.

Fitri, Anissa Nur, et.al. (2015). "Perlindungan Hak-Hak Anak dalam Upaya Peningkatan Kesejahteraan Anak” Prosiding Penelitian \& Pengabdian Kepada Masyarakat, 2(1). http://journal.unpad.ac.id/prosiding/article/view/13235.

Fitri, Annisa, et.al. (2017). "Perencanaan Pembelajaran Kurikulum 2013 Pendidikan Anak Usia Dini” Jurnal Ilmiah Potensia, 2(1). https://ejournal.unib.ac.id/index.php/potensia/article/view/3032.

Gunawan, Imam. (2011). "Evaluasi Program Pembelajaran” Jurnal Pendidikan, 17(1). http://e-journal.unipma.ac.id/index.php/JP/article/view/108.

Fitriani, Rini. (2016). "Peranan Penyelenggara Perlindungan Anak dalam Melindungi dan Memenuhi Hak-Hak Anak" Jurnal Hukum Samudra Keadilan, 11(2). https://www.ejurnalunsam.id/index.php/jhsk/article/view/42.

Handayani, Novia Amarta \& Jumadi. (2021). "Analisis Pembelajaran IPA Secara Daring pada Masa Pandemi Covid-19” Jurnal Pendidikan Sains Indonesia, 9(2). https://doi.org/10.24815/jpsi.vgi2.19033.

Hanief, Muhammad. (2016). "Menggagas Teknik Supervisi Klinik Sebagai Upaya Peningkatan Mutu Pembelajaran” Vicratina: Jurnal Pendidikan Islam, 1(2). http://riset.unisma.ac.id/index.php/fai/article/view/162.

Hardana, Ali. (2015). "Manajemen Sumber Daya Insani” Al-Masharif: Jurnal Ilmu Ekonomi dan Keislaman, 3(1). http://194.31.53.129/index.php/Almasharif/article/view/1057.

Hasanah, Uswatun. (2018). "Metode Pengembangan Moral dan Disiplin Bagi Anak Usia Dini” Martabat: Jurnal Perempuan dan Anak, 2(1). http://ejournal.iain- 
tulungagung.ac.id/index.php/martabat/article/view/990.

Hidayat, Tatang \& Abas Asyafah. (2019). "Konsep Dasar Evaluasi dan Implikasinya dalam

Evaluasi Pembelajaran Pendidikan Agama Islam di Sekolah” Al-Tadzkiyyah: Jurnal

Pendidikan

Islam,

$10(1)$.

http://ejournal.radenintan.ac.id/index.php/tadzkiyyah/article/view/3729.

Inawati, Asti. (2017). "Strategi Pengembangan Moral dan Nilai Agama untuk Anak Usia Dini” Al-Athfal: Jurnal Pendidikan Anak, 3(1). http://202.0.92.5/tarbiyah/index.php/alathfal/article/view/1422.

Ismail, Irvan. (2016). "Kinerja Pengawas Madrasah dalam Meningkatkan Kompetensi Guru Madrasah di Kabupaten Gorontalo” Jurnal Ilmiah Al-Jauhari, 1(1). http://journal.iaingorontalo.ac.id/index.php/aj/article/view/666.

Ita, Efrida. (2018). "Manajemen Pembelajaran Pendidikan Anak Usia Dini di TK Rutosoro Kecamatan Golewa Kabupaten Ngada Flores Nusa Tenggara Timur" Jurnal Dimensi Pendidikan dan Pembelajaran, 6(1). http://journal.umpo.ac.id/index.php/dimensi/article/view/889.

Khaironi, Mulianah. (2017). "Pendidikan Moral pada Anak Usia Dini” Jurnal Golden Age, 1(1). https://e-journal.hamzanwadi.ac.id/index.php/jga/article/view/479.

Khairuddin. (2020). "Implementasi Inovasi Manajemen Pembelajaran dalam Peningkatan Kualitas Pendidikan Agama Islam di Madrasah Aliyah Negeri 2 Model Medan” Disertasi. Universitas Islam Negeri Sumatera Utara Medan. http://repository.uinsu.ac.id/9560/.

Kristiawan, Muhammad \& Nur Rahmat. (2018). "Peningkatan Profesionalisme Guru Melalui Inovasi Pembelajaran” Jurnal Iqra’: Kajian Ilmu Pendidikan, 3(2). https://journal.iaimnumetrolampung.ac.id/index.php/ji/article/view/348.

Lilian, Vin, et.al. (2014). "Inovasi Manajemen Pembelajaran Sejarah (Studi Deskriptif Kualitatif di SMA Negeri 1 Ujan Mas)” Tesis. Universitas Bengkulu. http://repository.unib.ac.id/84.55/.

Lubis, Masruroh, et.al. (2020). "Pembelajaran Pendidikan Agama Islam Berbasis ELearning (Studi Inovasi Pendidik MTs. PAI Medan di Tengah Wabah Covid-19)” Fitrah: Journal of Islamic Education, 1(1). http://jurnal.staisumateramedan.ac.id/index.php/fitrah/article/view/1.

Mafaliha, Mardiyana. (2020). "Upaya Guru dalam Mengembangkan Karakter Religius Anak Usia Dini di RA Raudlotunnahdliyah Dusun Ngrawan Desa Dolopo Kecamatan Dolopo Kabupaten Madiun” Skripsi. IAIN Ponorogo. 
http://etheses.iainponorogo.ac.id/11432/.

Mardhiah, et.al. (2020). "Inovasi Manajemen Pembelajaran Melalui Model Hypnoteaching dalam Meningkatkan Minat dan Kemampuan Membaca Al-Qur'an Bagi Anak Pemulung di Kota Makassar” Muslim Heritage: Jurnal Dialog Islam dengan Realitas, 5(2). https://doi.org/10.21154/muslimheritage.v5i2.2302.

Maujud, Fathul. (2018). "Implementasi Fungsi-fungsi Manajemen dalam Lembaga Pendidikan Islam (Studi Kasus Pengelolaan Madrasah Ibtidaiyah Islahul Muta'allim Pagutan)" Jurnal Penelitian Keislaman, 14(1). https://doi.org/10.20414/jpk.v14i1.490.

Meisusdawati, Ike. (2011). "Pengawasan Kepala Madrasah Terhadap Proses Pembelajaran di Madrasah Tsanawiyah Negeri Pangean Kabupaten Kuantan Singingi” Skripsi. Riau: UIN Sultan Syarif Kasim Riau. http://repository.uinsuska.ac.id/478/.

Munawaroh, Hidayatu. (2017). "Pengembangan Model Pembelajaran dengan Permainan Tradisional Engklek Sebagai Sarana Stimulasi Perkembangan Anak Usia Dini” Jurnal Obsesi: Jurnal Pendidikan Anak Usia Dini, 1(2). https://doi.org/10.31004/obsesi.v1i2.19.

Nadlir, M. (2013). "Perencanaan Pembelajaran Berbasis Karakter" Jurnal Pendidikan Agama Islam, 1(2): 338-352. https://doi.org/10.15642/jpai.2013.1.2.338-352.

Nasrin. (2021). "Koordinasi Pengawas dan Kepala Madrasah dalam Meningkatkan Prestasi Kerja Guru MIN 8 Aceh Tenggara" Edu Society: Jurnal Pendidikan, Ilmu Sosial dan Pengabdian kepada Masyarakat, 1(1). http://jurnal.permapendissumut.org/index.php/edusociety/article/view/28.

Noor, Triana Rosalina. (2020). "Mengembangkan Jiwa Keagamaan Anak (Perspektif Pendidikan Islam dan Perkembangan Anak Usia Dini)" Kuttab: Jurnal Ilmu Pendidikan Islam, $4(2)$.

http://journalfai.unisla.ac.id/index.php/kuttab/article/view/269.

Notosrijoedono, R.A. Anggraeni. (2015). "Menanamkan Kecerdasan Moral Sejak Anak Usia Dini pada Keluarga Muslim” Jurnal Tarbiyah, 22(1). http://jurnaltarbiyah.uinsu.ac.id/index.php/tarbiyah/article/view/9.

Nurdyansyah \& Eni Fariyatul Fahyuni. (2016). "Inovasi Model Pembelajaran Sesuai Kurikulum 2013" Nizamia Learning Center. http://eprints.umsida.ac.id/296/. Nuriyah, Nunung. (2014). "Evaluasi Pembelajaran: Sebuah Kajian Teori” Edueksos: Jurnal Pendidikan Sosial dan Ekonomi, 3(1). 
https://www.syekhnurjati.ac.id/jurnal/index.php/edueksos/article/view/327.

Nurlaila. (2018). "Urgensi Perencanaan Pembelajaran dalam Peningkatan Profesionalisme Guru" Sustainable: Jurnal Kajian Mutu Pendidikan, 1(1). http://jurnal.kopertais5aceh.or.id/index.php/al-qiraah/article/view/124.

Nurmalitasari, Femmi. (2015). "Perkembangan Sosial Emosi pada Anak Usia Prasekolah"

$\begin{array}{lll}\text { Buletin Psikologi, } & \text { 23(2). }\end{array}$

https://journal.ugm.ac.id/buletinpsikologi/article/view/10567.

Oviyanti, Fitri. (2013). "Tantangan Pengembangan Pendidikan Keguruan di Era Global"

Nadwa: Jurnal Pendidikan Islam,

https://journal.walisongo.ac.id/index.php/Nadwa/article/view/562.

Pamela, Maria Vani, et.al. (2015). "Persepsi Masyarakat Lokal dan Masyarakat

Transmigrasi tentang Tanggung Jawab Orang Tua atas Pendidikan Anak” Jurnal

Pendidikan dan Pembelajaran Khatulistiwa, 4(1).

https://jurnal.untan.ac.id/index.php/ipdpb/article/view/8884.

Pane, Aprida \& Muhammad Darwis Dasopang. (2017). "Belajar dan Pembelajaran"

Fitrah: Jurnal Kajian Ilmu-ilmu Keislaman, 3(2). http://jurnal.iainpadangsidimpuan.ac.id/index.php/f/article/view/945.

Prabowo, Sugeng Listyo. (2010). "Perencanaan Pembelajaran pada Bidang Studi, Bidang

Studi Tematik, Muatan Lokal, Kecakapan Hidup, Bimbingan dan Konseling” UIN

Maliki Press. http://repository.uin-malang.ac.id/1616/.

Putriani, Pika. (2015). "Motivasi Orang Tua Menyekolahkan Anak di Pondok Pesantren Raudhatul Ulum” Skripsi. Universitas Muhammadiyah Palembang. http://repository.um-palembang.ac.id/id/eprint/211/.

Rahayu, Galih Dani Septiyan \& Dida Firmansyah. (2018). "Pengembangan Pembelajaran Inovatif Berbasis Pendampingan Bagi Guru Sekolah Dasar" Abdimas Siliwangi, 1(1). $\quad$ https://www.journal.ikipsiliwangi.ac.id/index.php/abdimassiliwangi/article/view/36.

Rahim, Ali. (2015). "Strategi Peningkatan Kualitas Pendidikan di Madrasah Aliyah Kabupaten Sidrap: Tinjauan Implementasi Kurikulum Tingkat Satuan Pendidikan” Lentera Pendidikan, $18(2)$.

http://103.55.216.56/index.php/lentera pendidikan/article/view/924.

Rahman, Abdul. (2018). "Urgensi Pedagogik dalam Pembelajaran dan Implikasinya dalam Pendidikan” Belajea: Jurnal Pendidikan Islam, 3(1). http://repository.iaincurup.ac.id/50/. 
Rahmat, Aibdi. (2017). “Manusia Sebagai Pemakmur Bumi” Manhaj: Jurnal Penelitian dan Pengabdian Masyarakat,

https://ejournal.iainbengkulu.ac.id/index.php/manhaj/article/view/757.

Rohmah, Fitri Nur. (2017). "Urgensi Evaluasi untuk Pendidikan” Fikrotuna: Jurnal Pendidikan dan Manajemen Islam, 5(1).

http://ejournal.kopertais4.or.id/madura/index.php/fikrotuna/article/view/2954.

Rosyad, Ali Miftakhu. (2019). "The Urgency of Learning Innovation on Islamic Religious

Study” Al-Afkar: Journal of Islamic Studies, 2(1). https://alafkar.com/index.php/Afkar Journal/article/view/41.

Sada, Heru Juabdin. (2017). "Kebutuhan Dasar Manusia dalam Perspektif Pendidikan Islam” Al-Tadzkiyyah: Jurnal Pendidikan Islam, 8(2). https://doi.org/10.24042/atjpi.v8i2.2126.

Saputro, Budiono. (2016). "Pengembangan Model Manajemen Pembelajaran Direct Instruction Berfokus Film dalam Pengantar Praktikum IPA" Holistik, 1(1). https://scholar.google.com/scholar?start=20\&q=+inovasi+manajemen+pembelaj aran\&hl=id\&as $\quad \mathrm{sdt}=0,5$.

Shahih, Ahmad. (2020). "Moral Kekhalifahan Manusia dalam Al-Qur'an Menurut Teori Ecotheology Islam: Studi Tafsir Tematik” Jurnal Perspektif, 4(2). https://www.perspektif.uinsgd.ac.id/index.php/JP/article/view/80.

Shalahudin, et.al. (2020). "Analisis Kritik Terhadap Pelaksanaan Pembelajaran PAI di Sekolah” Jurnal Pendidikan Islam, 11(2). http://digilib.uinsgd.ac.id/35519/.

Sholikhah, Siti, et.al. (2019). "Motivasi Orang Tua Menyekolahkan Anak di KB Aisyiyah 30 Surabaya” Pedagogi: Jurnal Anak Usia Dini dan Pendidikan Anak Usia Dini, 5(2). http://journal.um-surabaya.ac.id/index.php/Pedagogi/article/view/3612.

Siregar, Lis Yulianti Syafrida. (2016). "Pendidikan Anak dalam Islam” Bunayya: Jurnal Pendidikan Anak, 1(2). $\quad$ https://www.jurnal.arraniry.ac.id/index.php/bunayya/article/download/2033/1505.

Suardipa, I Putu \& Kadek Hengki Primayana. (2020). "Peran Desain Evaluasi Pembelajaran untuk Meningkatkan Kualitas Pembelajaran” Widyacarya: Jurnal $\begin{array}{lllll}\text { Pendidikan, Agama } \quad \text { B } & \text { 4(2). }\end{array}$ http://jurnal.stahnmpukuturan.ac.id/index.php/widyacarya/article/view/796/o. Sudrajat, Tedy. (2011). "Perlindungan Hukum Terhadap Hak Anak Sebagai Hak Asasi Manusia dalam Perspektif Sistem Hukum Keluarga di Indonesia” Kanun: Jurnal Ilmu Hukum, 13(2). http://e-repository.unsyiah.ac.id/kanun/article/view/6245. 
Sujatmoko, Emmanuel. (2010). "Hak Warga Negara dalam Memperoleh Pendidikan" Jurnal Konstitusi, $7(1)$.

https://jurnalkonstitusi.mkri.id/index.php/ik/article/view/208.

Supriadi, Dudun. (2017). "Impelementasi Manajemen Inovasi dan Kreatifitas Guru dalam Meningkatkan Mutu Pembelajaran” IJEMAR: Indonesian Journal of Education Management \& Administration Review, 1(2). https://jurnal.unigal.ac.id/index.php/ijemar/article/view/944.

Supriadi. (2020). "Konsep Manajemen Insani Sebagai Upaya Peningkatan Kinerja Guru di Madrasah” Auladuna: Jurnal Prodi Pendidikan Guru Madrasah Ibtidaiyah, 2(2). https://doi.org/10.36835/au.v2i2.417.

Suryapermana, Nana. (2017). "Manajemen Perencanaan Pembelajaran" Tarbawi: Jurnal Keilmuan Manajemen Pendidikan, 3(2). http://dx.doi.org/10.32678/tarbawi.v3io2.1788.

Syafaruddin, et.al. (2020). "Manajemen Pembelajaran Pendidikan Agama Islam di SDIT Bunayya Pandan Kabupaten Tapanuli Tengah” AULADUNA: Jurnal Pendidikan Dasar Islam, 7(1). http://repository.uinsu.ac.id/id/eprint/8966.

Tatu, Hasna R. (2019). "Pengendalian Pendidikan Terhadap Media Pembelajaran dalam Urgensi Pembelajaran Daring pada Masa Pandemi Covid-19” Jurnal Al-Himayah, 3(2). http://journal.iaingorontalo.ac.id/index.php/ah/article/view/2121.

Taubah, Mufatihatut. (2015). "Pendidikan Anak dalam Keluarga Perspektif Islam" Jurnal Pendidikan Agama Islam, 3(1).

http://jurnalpai.uinsby.ac.id/index.php/jurnalpai/article/view/41.

Thobroni, Ahmad Yusam. (2014). "Internalisasi Nilai-nilai Kesadaran Lingkungan Melalui Pendidikan (Perspektif Al-Qur'an dan Al-Hadits)" Jurnal Pendidikan Agama Islam, 2(1).

http://jurnalpai.uinsby.ac.id/index.php/jurnalpai/article/view/22.

Tonta, Norma, et.al. (2019). "Pelaksanaan Supervisi Akademik Pengawas dalam Pembinaan Guru PAI pada Madrasah Aliyah Pondok Pesantren Nurul Falah” Manajemen Pendidikan, 14(1).

http://journals.ums.ac.id/index.php/jmp/article/view/8523.

Trenggonowati, Dyah Lintang \& Kulsum. (2018). “Analisis Faktor Optimalisasi Golden Age Anak Usia Dini Studi Kasus di Kota Cilegon” Journal Industrial Servicess, 4(1). https://jurnal.untirta.ac.id/index.php/jiss/article/view/4088.

Ulfiyah, Faiz Nadhifatu. (2017). "Peran Guru dalam Mendidik Perilaku Ibadah Anak Usia 
Dini di RA Al-Hidayah Gombang Pakel Tulungagung” Skrispi. IAIN Tulungagung. http://repo.iain-tulungagung.ac.id/5552/.

Usman, A. Samad. (2017). "Tanggung Jawab Orang Tua Terhadap Pendidikan Anak dalam Perspektif Islam" Bunayya: Jurnal Pendidikan Anak, 2(1). http://103.107.187.25/index.php/bunayya/article/viewFile/1324/984.

Vitasari, Hamidah Nur. (2017). "Motivasi Orang Tua Menyekolahkan Anak di Sekolah Berbasis Islam (Studi Kasus di Desa Singosari Mojosongo Boyolali)" Skripsi. IAIN Salatiga. http://e-repository.perpus.iainsalatiga.ac.id/1954/.

Widiantar, Dian. (2016). "Implikasi Tugas dan Kewajiban Hidup Manusia dalam Konteks Pendidikan” Misykah: Jurnal Pemikiran dan Studi Islam, 1(2). http://journal.bungabangsacirebon.ac.id/index.php/misykah/article/view/17.

Widyanto, I Putu, et.al. (2020). "Implementasi Manajemen Pembelajaran Era Revolusi Industri 4.0 di Institut Agama Hindu Negeri Tampung Penyang Palangka Raya” Jurnal Smart, $6(1)$.

https://blasemarang.kemenag.go.id/journal/index.php/smart/article/view/981. Yin, Robert K. (2009). Case Study Research: Design and Methods. California: SAGE Inc. 